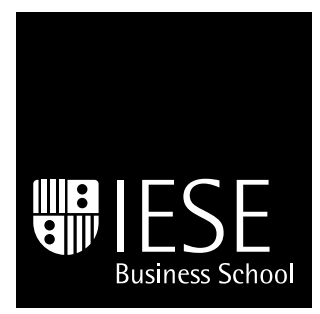

University of Navarra

\author{
HOW MUCH DO MIDDLE \\ MANAGERS MATTER, REALLY? \\ AN EMPIRICAL STUDY ON THEIR IMPACT \\ ON SUSTAINED SUPERIOR PERFORMANCE
}

Johanna Mair*

RESEARCH PAPER No 473

October, 2002

* Professor of General Management, IESE

Research Division

IESE

University of Navarra

Av. Pearson, 21

08034 Barcelona - Spain 


\title{
HOW MUCH DO MIDDLE MANAGERS MATTER, REALLY? AN EMPIRICAL STUDY ON THEIR IMPACT ON SUSTAINED SUPERIOR PERFORMANCE
}

\begin{abstract}
Prior research on middle managers has emphasized their vital role in the strategic and entrepreneurial process of established organizations. Yet we still know relatively little about how their actual behavior translates into superior performance. In this paper I examine how entrepreneurial behavior of middle managers - defined as innovative use of resources to explore and exploit opportunities - affects sustainable superior results at the subunit level. My analysis of 120 middle managers of a large European financial services firm suggests that entrepreneurial behavior triggers profit growth at the subunit level. Furthermore I find that individual characteristics-gender and education-are significantly related to superior performance
\end{abstract}

Keywords: Sustained superior performance, Middle managers, Entrepreneurial behavior, Profit growth 


\section{HOW MUCH DO MIDDLE MANAGERS MATTER, REALLY? AN EMPIRICAL STUDY ON THEIR IMPACT ON SUSTAINED SUPERIOR PERFORMANCE}

\section{Introduction}

Strategic management research is concerned with identifying the sources of sustained superior performance (Rumelt et al., 1994). Based on different theories and methodologies scholars have suggested market positions (Porter, 1980), idiosyncratic and inimitable firm-specific resources (Lippman et al., 1982; Wernerfelt, 1984) or dynamic capabilities (Teece et al., 1997) as its primary sources. Although important, the majority of these studies have concentrated on performance measured at the organizational level and investigated performance differences between firms or clusters of firms. Only a few have recognized the performance potential at the subunit level and examined variance within one company or division. Also, previous research has predominantly focused on the influence of top management on performance, i.e., on how strategic decisions taken at the top affect various dimensions of superior performance such as competitive advantage or above average returns. The impact of middle managers and their actions on sustained superior performance, on the other hand, has received only limited attention.

In this paper I complement existing research by emphasizing action and actual behavior instead of decision making, by focusing on middle managers instead of top managers, and last but not least, by stressing the importance of examining performance at the subunit level. In a nutshell, I explicitly examine how entrepreneurial behavior of middle managers -defined as the innovative use of resources to explore and exploit opportunitiesinfluences sustainable superior results at the subunit level.

My objectives are, first, to introduce an activity-based approach to unravel the myth of sustained superior performance; second, to illustrate how middle managers add value; and third, to propose entrepreneurial behavior as an effective tool for managing established organizations.

Literature in organizational behavior argues that superior performance can -to a large extent- be attributed to the person, while strategic management literature has traditionally emphasized situational characteristics such as size and or level of competitiveness as critical variables affecting superior performance. In this paper I furthermore attempt to reconcile both literatures and investigate the effect of personal attributes and characteristics of the units on sustained superior performance.

In the empirical part of the study I use multiple regression analysis (OLS) to analyze entrepreneurial behavior of 119 middle managers of a large European financial services firm and its impact on profit growth at the subunit level. Based on qualitative fieldwork I develop 
an original and context-specific measurement instrument to assess entrepreneurial activities, and combine subjective (survey) data on entrepreneurial behavior with objective data on performance collected over three consecutive years (1997-1999).

In the next section I briefly review the literature on middle managers. Subsequently I elaborate on entrepreneurial behavior as an effective means to manage established organizations and lay out the theoretical arguments for linking it to sustained superior performance, namely to profit growth. In the following section I summarize research design, data analysis, and present the results of the empirical test. To conclude, I discuss the main findings, contribution to the literature, and managerial implications.

\section{Review of the literature on middle managers}

Research on middle managers has a long tradition within the field of strategic management. Previous - mainly process oriented- research has shown that middle managers assume an active role in both strategy implementation and strategy formulation. On one hand they translate organizational goals and strategy into concrete actions (Uyterhoeven, 1972), and on the other, they convert autonomous managerial action into strategic intent (Burgelman, 1983a). In addition, exerting upward, downward and sideways influence, 'managers in the middle' ensure efficient allocation, transfer and sharing of resources and capabilities (Bower, 1970; Ghoshal et al., 1997; Nonaka, 1988).

More recently researchers have emphasized middle managers' role in fostering entrepreneurial initiative in established organizations (see Hornsby et al., 2002 for a review). Middle managers are seen as vital to translate entrepreneurial initiatives developed at the front into organizational outcomes (Burgelman, 1983b). "Entrepreneurial" middle managers not only seek and pursue opportunities; they also bring them to life (Kanter, 1982). They actively promote ideas, build support, overcome resistance, and ensure that the innovative ideas are implemented and followed up (Howell et al., 1990).

However, while over the last decades we have gained a comprehensive understanding about the nature of middle managers' activities, we still know relatively little about their consequences for tangible performance. The few existing empirical studies are typically based on abstract categories of activities and assess performance implications at the organizational level. Woolridge et al. (1990), for example, relate middle managers' involvement in strategy making to performance measured at the organizational level. Little empirical research has looked at the effect of specific managerial activities on sustained performance at the subunit level, the most appropriate level to assess middle managers' impact.

In this paper I develop a fine-grained, context-specific measurement instrument to capture middle managers' actual behavior and assess sustained superior performance in terms of profit growth at the subunit level. I delimit my analysis to activities constituting entrepreneurial behavior -pursuing opportunities by innovative use of resource combinations- as these activities have frequently been associated with various dimensions of superior performances, such as competitive advantage and above-normal returns (Covin et al., 1999), growth (Penrose, 1959), and renewal (Ghoshal et al., 1995).

In the next sections I conceptualize middle managers' entrepreneurial behavior as a distinct style of managing established organizations and delineate the theoretical arguments for linking it to profit growth. 


\section{Theoretical arguments}

\section{Entrepreneurial Behavior as a Managing Style}

While business press and scholars alike typically conceive entrepreneurial behavior as an efficacious means to stimulate continual innovation, growth, and value creation (Hamel, 1999), rigorous empirical research linking entrepreneurial activities and superior performance remains scarce (Covin et al., 1991; Zahra et al., 1993). Furthermore, previous empirical studies have mainly looked at grand entrepreneurship, i.e., discrete entrepreneurial events such as the creation of new organizations (Gartner, 1988), new ventures (Vesper, 1985), new entry (Lumpkin et al., 1996), or new product development (von Hippel, 1977). While important for traditional entrepreneurship research, such narrow definitions of entrepreneurship remain inapplicable to various entrepreneurial phenomena occurring in large established companies. In this study I adopt a less heroic view and emphasize day-today entrepreneurship aimed at "getting things done in an entrepreneurial -innovative and unusual- way".

Following a behavioral research tradition (Stevenson et al., 1990), I view entrepreneurship within established organizations as a set of interlocking opportunity-based activities by competent and purposeful individuals, who -through their actions- can make a difference. For the purpose of this paper I define entrepreneurial behavior as

... a set of activities and practices by which individuals at multiple levels autonomously generate and use innovative resource combinations to identify and pursue opportunities.

While innovation, autonomy and opportunities are defining elements of entrepreneurship in general (Lumpkin et al., 1996; Miller, 1983; Stevenson et al., 1990), entrepreneurial behavior within large organizations is distinct. It includes a spectrum of activities ranging from independent/autonomous to integrative/cooperative behavior (Ghoshal et al., 1994; Kanter, 1982). Within large organizations "entrepreneurial managers" need to build on the uniqueness of their units and at the same time profit from similarities with other units. They need to continuously balance "exploration" of new resource combinations with "exploitation" of existing organizational capabilities (Normann, 1977). Moreover, entrepreneurial behavior within such companies is not constrained by organizational boundaries but rather implies heedful stretching of such boundaries.

Opportunities to act entrepreneurially arise within and outside the business unit. As such, middle managers can become entrepreneurial, first, in the way they lead and guide their subordinates, second, in the way they build and organize their unit, and last but not least, in the way they meet challenges from customers and markets (Mair, 2001). It is the set of these activities that is seen as vital to induce sustainable superior performance at the subunit level.

\section{Linking Entrepreneurial Behavior and Sustained Superior Performance}

This paper suggests that entrepreneurial behavior of middle managers stimulates sustainable superior performance -measured in terms of profit growth-in the units they are responsible for.

Growth per se hardly represents an organizational goal in itself, and neither is it a guarantee for value creation (Canals, 2001). Profit growth, on the other hand, integrates 
growth and profitability, two of the main aspects of economic performance, and provides a more adequate point of reference for superior performance. It reflects a company's ability to innovate, to stay in close touch with customers and markets, to enhance employee commitment, and attract investors (Canals, 2001), and is viewed as a viable indicator for organizational effectiveness, value creation, and sustained competitiveness (Prahalad, in Stoneham, 1995). Despite its relevance, profit growth has received only limited attention in empirical studies and therefore still remains a highly elusive phenomenon. This paper builds on theoretical insights from various streams of research and attempts to empirically elucidate the sources for variation in profit growth within established organizations.

One of the first to explicitly investigate growth and its origins was Edith Penrose (1959). In her "theory of the firm" she asserts that growth critically depends on individual managers carrying out new ideas. "Entrepreneurial services", defined as innovative use of resources, are central to purposive and effective (growth-oriented) behavior, and are required in all organizations (Penrose, 1959). A number of authors broadened this argument to discuss the role of managerial competence. Ghoshal et al. (1999), e.g., stress the importance of quality of managerial actions in eliciting growth, and Normann (1977) points to the reciprocal relations between vision and concrete managerial action as a basic condition for growth.

The main theoretical argument of this paper, i.e., the positive link between middle managers' entrepreneurial behavior and profit growth, is also substantiated by state-of-the-art economic theory. According to the "new theory of economic growth", it is not capital or raw materials that trigger growth but individuals (and companies) that explore and implement new and better ways of doing things (Romer, 1989).

Two of the defining elements of entrepreneurial behavior, innovation and opportunities, are particularly associated with profit growth. Opportunities, conceived as future states that are both desirable and feasible (Stevenson et al., 1990), make growth possible, while innovative approaches to pursue them ensure profitability. Innovation as viewed in this paper is not limited to technological development but can be understood as a process through which resources are developed and utilized to generate higher quality or lower cost processes, products and services.

It is important to note that opportunities arise inside and outside the organization. Innovative approaches to capture opportunities outside the subunit or organization, for example, include proactive ways to search and pursue business and market opportunities as well as to approach customers. Such activities elicit first-mover advantages, which in turn create sustainable competitive advantage and result in profit growth. Inside the business unit, resources can be employed innovatively to develop or adapt products and processes, to lead people, and to organize and structure the unit. Approaching processes and procedures in innovative ways can result in the building of dynamic organizational capabilities, which in turn stimulate profit growth and overall organizational effectiveness and competitiveness (Teece et al., 1997).

Based on these arguments I propose

Proposition: Middle managers' entrepreneurial behavior has a positive effect on profit growth in the unit they are responsible for. 


\section{Research Design}

I chose a one-company research design to attentively capture the phenomenon, and to develop context-specific measurement instruments. This also allowed me to reduce "noise" by holding constant several important determinants of entrepreneurial behavior at the firm level, such as incentive systems, corporate culture, and official information flows.

\section{Setting}

In 1997, ABN Amro -a large Dutch financial service company- launched a project to promote entrepreneurial behavior, and accordingly reshuffled its operations in the Netherlands. It split the domestic market into approximately 200 micro markets and appointed an area manager for each of these newly created independent units. Each unit belonged to one of 11 regional units, and area managers, although autonomous in principal, formally reported to their general regional manager. Area managers were expected to manage their unit in an entrepreneurial way and diffuse the entrepreneurial spirit throughout the organization. In contrast to their tasks in similar positions before the launch of this specific project, area managers became increasingly accountable for the financial results of their unit, and had considerable autonomy in organizing their unit as well as in approaching customers and employees. It is the activities of these area managers -middle managers- and their impact on profit growth in their areas (subunit) that is at the center of this study.

\section{Sample and procedures}

Following March et al. (1997), who predict retrospective biases in self-reported performance variables but not in assessing independent variables, I used objective sources (company archives) to collect performance data for the period 1997-1999, and relied on selfreported data to assess entrepreneurial behavior.

\section{Procedures}

The data collection process included: 1) forty semi-structured interviews (with middle managers, their bosses and subordinates) to operationalize entrepreneurial behavior and develop an adequate measurement instrument; 2) a comprehensive questionnaire completed by middle managers to assess entrepreneurial behavior; and 3) the collection of objective performance data over time.

\section{Sample}

Out of a total population of 207 area managers, 150 managers answered the questionnaire (response rate of 72\%). To follow performance over time (1997 until the end of 1999) and to ensure comparability I delimited the analysis to the 121 middle managers that assumed their job with the launch of the entrepreneurial project at ABN Amro at the beginning of 1997. Two additional areas (units) had to be excluded from the analysis: the national airport because of its particularities with respect to both business and inhabitants, and one area where no performance data were available. Thus the final sample $(\mathrm{N})$ consisted of 119 areas (units). 
I evaluated non-response biases by comparing regional distribution, size, and performance of the units in the "returned" sample with the ones in the "not-returned" sample. No significant differences were found. As suggested by the relevant literature, I eliminated social desirability effects as much as possible by clarifying introductions and accurate phrasing of questions (Rossi et al., 1983).

\section{Respondents}

The sample of managers who returned the questionnaire and started their job in 1997 exhibited the following characteristics: Four percent of all middle managers in the return sample were female, and $71 \%$ of all respondents were less than 50 years old. The educational level was quite elevated: $77.3 \%$ had enjoyed higher education (39\% hold university degrees). These results are consistent with the distribution in the overall population of middle managers working for ABN Amro in the Netherlands. On average, managers in the sample had been with the company for 22 years and were responsible for 59 employees. Depending on the size of unit the latter number ranged between 14 and 217 employees.

\section{Measures}

\section{Dependent Variables}

Profit growth was assessed over a period of three years. The profitability dimension was captured by the financial results (income margin), while the growth dimension was captured by an index comparing the results of 1997 with those of the end of 1999 (1997=100).

\section{Independent Variable}

I built on interviews with middle (area) managers, subordinates, bosses and internal/external experts to develop indicators forming a context-specific instrument to measure entrepreneurial behavior. Following the distinct steps suggested by the literature on scale development (Rossi et al., 1983), I generated different items and pre-tested the scale with a sample of middle managers. The final scale included questions about the extent to which middle managers engaged in particular entrepreneurial activities ( 1 "to no extent", to 7 "to a great extent"). The five items constituting the final scale (see Appendix) capture the main defining elements of entrepreneurial activity in large traditional organizations, i.e., innovation, autonomy and opportunity. They are targeted at activities related to the renewing of organizational processes and structure, to guiding employees, and last but not least to proactively approaching customers and markets. In other words, the items reflect the spectrum of activities associated with entrepreneurial management within an established organization (see Mair, 2001 for a detailed description of the scale development process). The final scale demonstrated highly satisfactory internal reliability (Cronbach alpha $=0.76$ ).

\section{Control variables}

To properly assess change in financial results (profit growth) I controlled for initial levels of financial results (Finkel, 1995). By controlling for the initial values, I take into account the likely negative correlation between initial scores on a variable and subsequent change, a phenomenon generally known as "regression to the mean". 
While literature in organizational behavior has extensively argued that superior performance can to a large extent be attributed to the person, strategic management literature has traditionally emphasized situational characteristics such as size and or level of competitiveness as critical variables affecting superior performance. Attempting to reconcile both literatures, I controlled for personal characteristics of the managers as well as for the particular characteristics of their units. Personal characteristics reflect gender, age, level of education, and professional background. I used dummy variables for all of these: gender (male / female), age (above / below 50), education (high: university or higher vocational education / secondary or primary school), and professional background (similar position as middle managers in same geographical location / different geographical location / another position within the domestic division).

To control for unit-specific characteristics I included variables reflecting the particular region where the unit was located, the size of the unit, the level of wealth, and the level of competition in the unit. I used dummy variables to indicate the unit (in an 11region total); the number of full time employees as a proxy for the size of the unit; the average prices of houses as an indicator for the level of wealth in the unit; and the ratio of ABN Amro bank branches divided by the total number of bank branches in the unit as an estimate for the level of competition.

\section{Data Analysis and Results}

I conducted multiple regression analysis (OLS) to test the proposition that middle managers instigate profitable growth by engaging in entrepreneurial behavior. Table 1 presents the descriptive statistics (means and standard deviations) and Pearson correlation matrix for all variables. To check for multicollinearity I assessed VIF and tolerance statistics, which both indicate acceptable levels and did not compromise the theoretical and empirical validity of the study. 


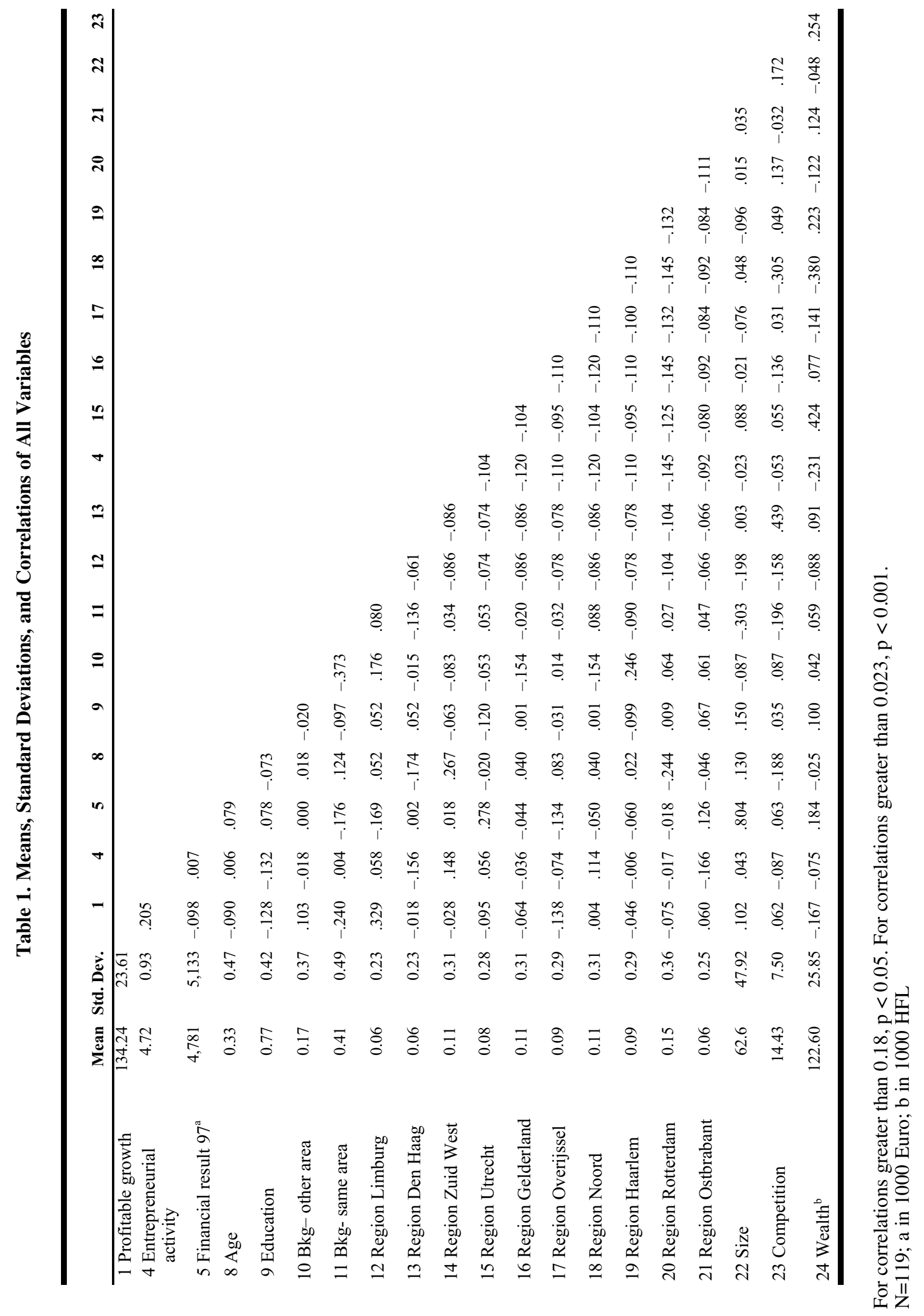


Table 2 illustrates the results of the multiple regression analysis. The full model was highly significant $(\mathrm{F}=2.71, \mathrm{p}<0.001)$. It explained $33 \%$ of the variance in profitable growth. The main proposition of this paper was supported: entrepreneurial behavior of middle managers exerted a significant and positive effect on profit growth $(0.16, p<0.1)$ even after controlling for personal and unit-specific characteristics.

Table 2. Results of Multiple Regression: Effect of Entrepreneurial Activity on Profitable Growth

\begin{tabular}{|c|c|}
\hline Independent Variable & $\begin{array}{l}\text { Profitable } \\
\text { growth }\end{array}$ \\
\hline Entrepreneurial activity & $0.16 *$ \\
\hline \multicolumn{2}{|l|}{ Initial level of performance } \\
\hline Financial results in 1997 & -0.16 \\
\hline \multicolumn{2}{|l|}{ Personal characteristics } \\
\hline Gender $(1=$ male $)$ & $-0.15^{*}$ \\
\hline Age $(1=$ below 50$)$ & -0.01 \\
\hline Education ( 1 = higher education) & $-0.31 * * *$ \\
\hline $\begin{array}{l}\text { Background: similar position as area manager } \\
\text { in the same geographical location }\end{array}$ & $-0.35 * * *$ \\
\hline $\begin{array}{l}\text { Background: similar position as area manager } \\
\text { in a different geographical location }\end{array}$ & -0.14 \\
\hline \multicolumn{2}{|l|}{ Characteristics of area } \\
\hline Region Limburg & 0.17 \\
\hline Region Den Haag & -0.04 \\
\hline Region Zuid West & -0.14 \\
\hline Region Utrecht & -0.21 \\
\hline Region Gelderland & -0.18 \\
\hline Region Overijssel & $-0.25^{*}$ \\
\hline Region Noord & -0.13 \\
\hline Region Haarlem & -0.13 \\
\hline Resion Rotterdam & -0.18 \\
\hline Region Oostbrabant & 0.10 \\
\hline Competition & -0.10 \\
\hline Size & 0.11 \\
\hline Wealth & -0.03 \\
\hline $\mathrm{F}$ & $2.71 * * *$ \\
\hline $\mathrm{R}^{2}$ & 0.33 \\
\hline
\end{tabular}


Besides the principal independent variable, a number of variables reflecting personal characteristics significantly affected profit growth. Gender had a significant negative effect on profit growth $(-0.15, \mathrm{p}<0.1)$, suggesting that units managed by female managers performed better than units managed by male managers. However, it is important to note that the number of female area managers is relatively small. Only $3.4 \%$ of the managers in the sample are female. The level of education had a highly significant negative effect on profit growth $(-0.31, \mathrm{p}<0.001)$, suggesting that units managed by managers with university degrees or higher vocational training economically perform worse than those run by managers that have completed only primary or secondary education. Last but not least, the professional background of middle managers also significantly affected profitable growth. I applied three categories to characterize the middle managers' background: 1) managers who assumed a different position in a different geographical location before 1997; 2) managers who assumed a similar position within the same geographical location; and 3) managers who assumed a similar position in a different geographical location. Managers who did not change position and location exhibited a significantly lower growth in profits $(-0.35, \mathrm{p}<0.001)$ than their colleagues who changed both content and place.

In contrast to variables reflecting personal characteristics, control variables regarding the specific business units did not exert significant effects on profit growth. The only exception consisted of units in the region of Overijssel, which revealed significantly lower levels of profit growth than the region of Amsterdam.

Last but not least, the initial level of financial results did not exert any significant effect on the level of profitable growth in the individual unit.

\section{Discussion and implications}

In this study I advanced and tested the idea that middle managers' entrepreneurial behavior, conceptualized as their innovative use of resource combinations to explore and exploit opportunities, triggers profit growth within subunits. While prior literature in strategic management has largely neglected middle mangers' potential to achieve sustained superior performance, my analysis reveals that their entrepreneurial behavior is significantly associated with profit growth and therefore constitutes an important lever to create sustained superior performance in established organizations.

This finding corroborates earlier, mainly theoretical, claims about the importance of the quality of managerial actions in eliciting superior performance and growth (Ghoshal et $a l .$, 1999). Furthermore, it substantiates Penrose's idea that growth critically depends on individual managers carrying out new ideas and engaging in "entrepreneurial services" (Penrose, 1959). This is an idea that has been followed up on recently by scholars advocating a "new theory of economic growth" and proposing that it is individuals (and companies) exploring and implementing new and better ways of doing things that trigger growth and not capital or raw materials (Romer, 1989).

In addition, the results suggest that personal characteristics of the entrepreneurial actors -largely ignored by previous strategic management research- do matter. According to my data, female middle managers -although representing only a small percentage of the overall population- do significantly better in achieving profit growth in their units. The same holds for managers with a relatively lower level of education. Managers holding degrees from primary or secondary school seem to be more successful in triggering profit growth in 
middle management positions than their more highly educated colleagues. One interpretation of this finding goes back to the "socially created" perception of the job of middle managers. Very often middle management positions are merely considered as "necessary" steps on the career ladder within large organizations. As for many career-oriented managers holding university or comparable degrees they represent a temporary placement on the way to the top (management), the relative effort put into managing the unit is moderate. On the other hand, for managers with a lower educational background, middle manager positions represent a superb opportunity to demonstrate their management competence. Furthermore, as these managers in general hold their positions for longer periods of time, they also tend to put in more effort and "care" more. The data also reveal a significant effect of the professional background of middle managers on profit growth, suggesting that entrepreneurial efforts might be more successful if combined with a change in geographical location. In contrast to the predictions of traditional strategic management literature, situation and business unitspecific control variables do not exert significant effects on profit growth.

\section{Contribution, Limitations and Future Research}

This paper integrates literatures on middle mangers, the sources of sustained superior performance, and entrepreneurship within established organizations. It complements and advances existing research as follows: first, in contrast to prior research on middle managers, I go beyond describing roles and task of effective middle managers and offer insights on how specific actions aligned with the strategic vision of an organization translate into superior performance.

Second, the paper tackles the elusive phenomenon of sustained superior performance within large organizations. I complement and extend existing literature by elucidating how sustained superior performance-measured in terms of profit growth - is generated through distinct managerial activities at the subunit level. Hence, the study corroborates earlier claims that growth is not merely based on capital and raw materials but significantly depends on human initiative and creativity (Canals, 2001; Ghoshal et al., 1999; Penrose, 1959).

Third, I broaden existing literature on entrepreneurship within established organizations by adopting a less heroic view and emphasizing day-to-day entrepreneurship. Expanding the range of activities constituting entrepreneurial behavior, I offer a conceptualization that is applicable to a number of phenomena in large traditional organizations that would be excluded if merely looking at grand entrepreneurship, i.e., new venture creation or new product development.

Last but not least, the paper addresses and fills methodological gaps detected in previous research on middle managers and entrepreneurship within established firms. I adopted methods appropriate for an "infant field" lacking an advanced paradigm and concentrated on linking specific managerial activities to superior results at the subunit level rather than testing general theory (Bygrave, 1989; Goodman et al., 1983; Scott, 1977). Also, while traditional research mainly remained on the descriptive level I developed fine-grained context-specific measurement instruments based on qualitative insights to assess effective (entrepreneurial) behavior. Adequate measurements are fundamental for further theory development as well as for deriving meaningful implications for managerial practice (Lumpkin et al., 1996).

Nonetheless, a few limitations of the study and suggestions for future research should be pointed out. First, while the exploratory nature of the research project called for a 
one-company research design, additional studies are needed to establish external validity of the measurement instrument and to allow for a generalization of the findings.

Second, profit growth was assessed by taking into consideration the three years succeeding the launch of the entrepreneurial project at ABN Amro. It could be argued that to accurately estimate time lag effects a larger time horizon needs to be considered (Zahra et al., 1999). Third, although capturing behavior over three years, for accessibility reasons entrepreneurial activity was assessed at one point in time; future analysis would benefit from measuring entrepreneurial activity longitudinally, i.e., at various points over time. Last but not least, future research would also gain from controlling for past performance. In this study, as units and management positions were newly created in 1997, data on past performance and activities did not exist.

\section{Implications for Managerial Practice}

Contrary to the popular press, which has repeatedly described middle managers as "corporate dinosaurs", this study suggests that middle managers do add value. Their entrepreneurial behavior is significantly associated with sustained superior performance. The implications for top management are straightforward. We know that top management assumes a critical role in fostering entrepreneurial behavior (Ghoshal et al., 1994). However, this role cannot be limited to delineating an appropriate strategic vision, shaping formal organizational structure and processes, incentive and information systems, or providing the necessary resources. To make entrepreneurial approaches sustainable and profitable top management needs to mold the "behavioral" context; i.e., it needs to empower middle managers (Spreitzer, 1996) and build the appropriate levels of support, stretch, discipline and trust, to nurture entrepreneurial initiative at the subunit level (Ghoshal et al., 1994)

\section{References}

Bower, J. L., 1970, Managing the Resource Allocation Process: A Study of Corporate Planning and Investment, Harvard Business Press: Boston, MA.

Burgelman, R., 1983a, "A Model of the Interaction of Strategic Behavior, Corporate Context and the Concept of Strategy", Academy of Management Review 8(1): 61-70.

Burgelman, R. A., 1983b, "Corporate entrepreneurship and strategic management: insights from a process study", Management Science 29: 1349-1364.

Bygrave W. D., 1989, “The Entrepreneurship Paradigm (I): A Philosophical Look At Its Research Methodologies”, Entrepreneurship Theory and Practice 14(1): 7-26.

Canals, J., 2001, "How to Think About Corporate Growth?", European Management Journal 19(6): 587-598.

Covin, J. G and M. P. Miles, 1999, "Corporate entrepreneurship and the pursuit of competitive advantage", Entrepreneurship Theory and Practice 23(3): 47-63.

Covin, J. G. and D. P. Slevin, 1991, "A Conceptual Model of Entrepreneurship As Firm Behavior", Entrepreneurship Theory and Practice 16(1): 7-25. 
Gartner, W. B., 1988, “'Who is an entrepreneur?' is the wrong question”, American Journal of Small Business 12(4): 11-32.

Ghoshal, S. and C. Bartlett, 1994, "Linking Organizational Context and Managerial Action: The Dimensions of Quality of Management", Strategic Management Journal 15: 91112.

Ghoshal, S. and C. Bartlett, 1995, "Building the Entrepreneurial Corporation: New Organizational Processes, New Managerial Tasks", European Management Journal 13(2): 139-155.

Ghoshal, S. and C. A. Bartlett, 1997, The Individualized Cooporation: A Fundamentally New Approach to Management.

Ghoshal, S., C. A. Bartlett and P. Moran, 1999, "A New Manifesto for Management", Sloan Management Review (Spring): 9-20.

Goodman, P. S., R. S. Atkin and F. D. Schoorman, 1983, "On the Demise of Organizational Effectiveness Studies", in K.S. Cameron, D.A. Whetten (Eds.), Organizational Effectiveness - A Comparison of Multiple Models, Academic Press, Inc.: San Diego.

Hamel, G., 1999, “Bringing Silicon Valley inside”, Harvard Business Review 77(5): 70-84.

Hornsby, J. S., D. F. Kuratko and S. A. Zahra, 2002, "Middle managers' perception of the internal environment for corporate entrepreneurship: Assessing a measurement scale”, Journal of Business Venturing 17: 253-273.

Howell, J. M. and C. A. Higgins, 1990, "Champions of Change", Ivey Business Quarterly (Spring 1990).

Kanter, R. M., 1982, “The middle manager as innovator”, Harvard Business Review 60(4): 95-105.

Lippman, S. and R. Rumelt, 1982, "Uncertain imitability: an analysis of interfirm differences in efficiency under competition", Bell Journal of Economics 13: 418-438.

Lumpkin, G. T., G.G. Dess, 1996, "Clarifying the entrepreneurial orientation construct and linking it to performance", Academy of Management Review 21(1): 135-172.

Mair, J., 2001, "Entrepreneurial Behavior in A Large Traditional Organization: Exploring Nature, Key Drivers and Performance Implications", Department of Strategy, INSEAD: Fontainebleau.

March, J. G. and R. I. Sutton, 1997, "Organizational performance as a dependent variable", Organization Science 8(6): 698-706.

Miller, D., 1983, "The correlates of entrepreneurship in three types of firms", Management Science 29(7): 770-791.

Nonaka, I., 1988, "Toward Middle-Up-Down Management: Accelerating Information Creation", Management Science (Spring): 9-18. 
Normann, R., 1977, Management for Growth, John Wiley \& Sons: Chichester.

Penrose, E., 1959, The Theory of the Growth of the Firm (3rd (1995) ed.), Oxford University Press: Oxford.

Porter, M., 1980, Competitive Strategy, Free Press: New York.

Romer, P. M., 1989, "Capital accumulation in the theory of long-run growth", in R.J. Barro (Ed.), Modern Business Cycle Theory, Harvard Univerity Press: Cambridge, MA.

Rossi, P. H., J. D. Wright and A.B Anderson (Eds.), 1983, Handbook of Survey Research, Academic Press Inc: San Diego.

Rumelt, R., D. Schendel and D. Teece, 1994, Fundamental Issues in Strategy, Harvard University Press: Cambridge, MA.

Scott, W. R., 1977, "Effectiveness of Organizational Effectiveness Studies", in P.S. Goodman, J.M. Pennings (Eds.), New Perspectives on Organizational Effectiveness, Jossey-Bass: San Francisco.

Spreitzer, G., 1996, "Social Structural Characteristics of Psychological Empowerment", Academy of Management Journal 39(2): 483-504.

Stevenson, H. H., J.C., Jarillo, 1990, “A paradigm of entrepreneurship: entrepreneurial management", Strategic Management Journal 11: 17-27.

Teece, D. J., G. Pisano, A. Shuen, 1997, “Dynamic Capabilities and Strategic Management”, Strategic Management Journal, 18(7): 509-533.

Uyterhoeven, H., 1972, “General Managers in the Middle”, Harvard Business Review 67(5): 136-145.

Vesper, K. H., 1985, “A new direction, or just a new label?”, in J. J. Kao, H. H. Stevenson (Eds.), Entrepreneurship: What it is and how to teach it: 62-76. Harvard Business School: Boston.

Von Hippel, E., 1977, "Successful and failing internal corporate ventures -an empirical analysis", Industrial Marketing Management 6(3): 163.

Wernerfelt, B., 1984, “A resource-based view of the firm”, Strategic Management Journal 5(2): 171-180.

Woolridge, B., S.W. Floyd, 1990, “The Strategy Process, Middle Management Involvement, and Organizational Performance", Strategic Management Journal, 11: 231-241.

Zahra, S. A., Covin J. G., 1993, "Business strategy, technology policy and firm performance", Strategic Management Journal 14(6): 451-178.

Zahra, S. A., D. F. Jennings, D. F. Kuratko, 1999, "The antecedents and consequences of firm-level entrepreneurship: The state of the field", Entrepreneurship Theory and Practice 24(2): 45-65. 


\section{Appendix \\ HOW MUCH DO MIDDLE MANAGERS MATTER, REALLY? AN EMPIRICAL STUDY ON THEIR IMPACT ON SUSTAINED SUPERIOR PERFORMANCE}

\section{Scale to assess entrepreneurial activity} behavior.

The following questions aimed at measuring the managers' level of entrepreneurial

Please indicate whether you engaged in the particular activities described below.

If you did not please circle 1, if you did engage in the activity, please specify from 2-7 the level of effort you put in it.

$\begin{array}{lllllllll}\text { to no extent } & 1 & 2 & 3 & 4 & 5 & 6 & 7 & \text { to a great extent }\end{array}$

I understand that in managerial reality it is rarely (seldom) possible to perform all activities one would like to because of time and organizational restrictions. Please bear in mind that I am interested in a realistic picture of YOUR work as a rayon manager. Therefore it is important that you indicate your "actual" behavior and NOT what you consider as an "ideal" pattern if there were no constraints (restrictions).

- $\quad$ Changing procedures to facilitate client contact within the rayon*

- Promoting entrepreneurial behavior of employees with initiatives that went beyond the ones suggested by head-office

- $\quad$ Proactively approaching new customers

- Actively investigating new market opportunities within the rayon

- Encouraging your employees to develop new ideas on how to do business

* The term "rayon" refers to area (subunit) 